\title{
Research Notes
}

\section{Current Status of East Asian Collections in American Libraries}

\section{TSUEN-HSUIN TSIEN}

This study ${ }^{1}$ of the East Asian collections in American libraries in 1975 provides new data on the current status of resources, growth rate, geographical distribution, acquisitions, cataloging, personnel, fiscal support, unit capabilities and cost, use patterns, and services. The analysis is based on information from ninety-three libraries, including twenty-two not previously reported. ${ }^{2}$

Of the collections in this survey, eighty-nine are located in the United States, three in Canada, and one in Mexico. About one-half of them were established before, the other half since, I960 (Table I). Sixty-six of the collections are in university and college libraries, six in federal libraries, seven in public libraries, and fourteen in museum and special libraries. The size of the collections varies from a few thousand to as many as over a million volumes-with I I having over 200,000 volumes; 5 between I 00,000 and 200,000 volumes; 43 between I0,000 and I00,000 volumes; and 34 under 10,000 volumes. The incorporation of East Asian materials in branches of public libraries is a new trend, primarily for providing materials in vernacular languages to minority groups in the local community. ${ }^{3}$

\section{Resources, Growth, and Geographical Distribution}

As of 30 June 1975 , the total holdings of the ninety-three collections consisted of more than 2.6 million titles in 6.7 million volumes. These included $\mathrm{r} .4$ million titles in 4 million volumes in Chinese; one million titles in 2.4 million volumes in Japanese; 95,000 titles in 200,000 volumes in Korean; and 45,000 volumes in Manchu, Mongol, Tibetan, Moso, and other East Asian languages (Table I). Western-language materials are not included in the tabulation; their location is uncertain and reporting is inconsistent, thus a count would be meaningless.

Tsuen-Hsuin Tsien is Professor of Chinese Literature, and Curator of the Far Eastern Library at the University of Chicago.

${ }^{1}$ This project was cosponsored by the Committee on East Asian Libraries of the Association for Asian Studies and the ACLS-SSRC Task Force on (Chinese) Libraries and Research Materials, and supported by a grant of the American Council of Learned Societies and Social Science Research Council. The author wishes to acknowledge with gratitude the technical advice of Professor William L. Parish, $\mathrm{Jr}$. and the research assistance of Mr. James $\mathrm{K}$. M. Cheng in the preparation of this report.
${ }^{2}$ The full report-including an introduction, I 2 tables, 4 appendixes, a directory of East Asian Collections in American libraries, and an index-is published by the Center for Chinese Research Materials of the Association of Research Libraries, Washington, D.C., 1976 . For previous surveys, see note under Table 2.

${ }^{3}$ Besides those included in the tabulation, a few other public libraries (including the Boston Public Library, California State Library, Hawaii State Library, Oakland Public Library, San Francisco Public Library, Toronto Public Library, and that in Washington, D.C.) are known to possess some materials in East Asian languages. 
TABLE 1

HOLDINGS OF EAST ASIAN MATERIALS IN AMERICAN LIBRARIES

as of June 30, 1975

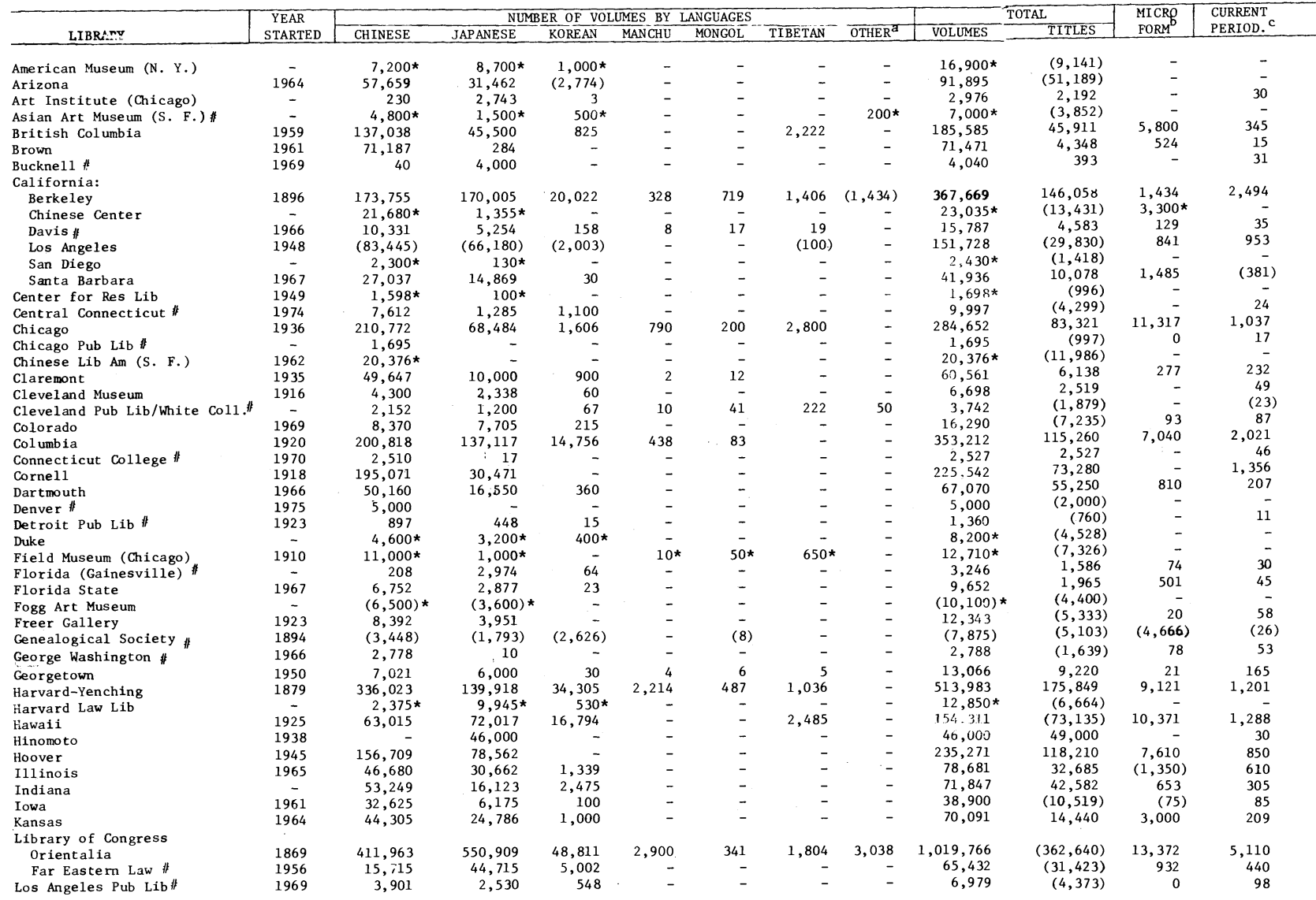


Maryland

Metropolitan Museu

Miami

Michigan (Ann Arbor)

Michigan (East Lansing)

Military Acade

Nat Agr Lib

Nat Lib of Medicine

Nebraska

Nelson Gallery

New York Bot Garde

Research Librarie

New York State: New Paltz

North Carolina

Northwester

Ober1 in

ohio State

Oregon

Pennsylvania

Pittsburgh

Princeton

Royal Ontario Museum

Rutgers 非

Ratgers \#

San Francisco State \#

St. John's
Seatt le Pub Lib

Seton Hall

State Departmen

Toronto

Washington (Seattle):

Far Eastern Library

Washington State

Washington University

Wisconsin

Yale

$\begin{array}{cr}- & 10, \\ 1969 & 10, \\ - & 3, \\ - & 2, \\ 1967 & 14, \\ 1948 & 169, \\ 1963 & 10, \\ 1972 & 3, \\ 1965 & 52, \\ 1960 & 15, \\ 1836 & (7, \\ - & 2, \\ 1933 & (2, \\ - & \\ & \\ 1911 & 8,\end{array}$

$10,281 *$
10,124
$3,180^{*}$
$2,253^{*}$
14,033
169,151
10,740
3,572
52,918
15,200
$(7,000)$
$2,500 *$
$(2,947)$
$100 *$

8,350

8,350
6,475

6,475
2,062
29,757

$15,577 *$
$(5,300)$

$(5,300)$
9,156

9,156
55,675

13,130
44,369

64,070

220,229
27,554

27,554
3,973

44,639

$(3,400)$

$(5,000)$

(673)

11,200 \%

2,000
6,141

$6039 \quad 60,316$

$1950 \quad(21,400)$

$\begin{array}{cr}1947 & 130,398 \\ - & 15,000\end{array}$

130,398
15,000
2,000

2,000
49,488

$\begin{array}{ll}1960 & (78,090 \\ 1878 & 164,135\end{array}$

$\begin{array}{rr}83,638 * & 3 \\ 3,241 & \\ 2,220^{*} & \\ 1,153 * & \\ 1,418 & 485 \\ 138,259 & 1,081 \\ 4,820 & 330 \\ 162 & \\ 15,691 & 268 \\ 17,000 & 1,500 \\ (16,000) & (2,000 \\ 1,000 * & \\ (2,000) & \\ 1,000 * & \\ & \end{array}$

$10,460 \quad 2,098$

2,331

106
1,339

$1,3,163^{*}$

$(130)$

9,383
11,716

24,063

8,180

10,659
5,062

$(750)$
$(2,950)$

$(2,950)$

$(1,142)$

6,, 000 *

22,500 *

43,946
$(1,020)$

49,084

500
32,798

$\begin{array}{rr}(33,090) \\ 93,024\end{array} \quad 3,233$

$\begin{array}{rr}(33,090) & (610) \\ 93,024 & 3,233\end{array}$

$2,434,858 \quad 198,797$

$8,926 \quad 2,838$

$27,492 \quad 5,472 \quad 6,702,278$

\begin{tabular}{|c|c|c|c|}
\hline $93,952 *$ & $(47,885)$ & $612 *$ & - \\
\hline 13,371 & $(8,862)$ & 78 & 14 \\
\hline $5,405 *$ & $(2,385)$ & & \\
\hline $3,407 *$ & $(1,479)$ & - & - \\
\hline 15,936 & 6,981 & 220 & 21 \\
\hline 308,491 & 131,090 & 28,961 & \\
\hline 16,140 & 15,770 & 1,720 & 610 \\
\hline 3,734 & 2,765 & 45 & 24 \\
\hline 68,955 & 14,776 & 483 & 450 \\
\hline 33,700 & $(15,213)$ & 200 & 180 \\
\hline$(25,000)$ & $(11,911)$ & - & 1,350 \\
\hline $3,500 *$ & $(1,971)$ & - & \\
\hline 4,947 & 2,100 & - & 36 \\
\hline $1,125 *$ & (554) & - & \\
\hline 22,040 & $(20,500)$ & 745 & 1,466 \\
\hline 9,008 & $(5,085)$ & & 19 \\
\hline 2,168 & $\begin{array}{r}(525) \\
(480)\end{array}$ & $\begin{array}{r}15 \\
675\end{array}$ & 60 \\
\hline 31,171 & $\begin{array}{l}(18,380) \\
(15,801)\end{array}$ & 1,675 & - \\
\hline $28,840 *$ & $\begin{array}{r}(15,801) \\
(3,189)\end{array}$ & $(300)$ & - \\
\hline $\begin{array}{c}(5,440) \\
9,457\end{array}$ & $\begin{array}{c}(3,189) \\
6,052)\end{array}$ & & $\begin{array}{r}5 \\
86\end{array}$ \\
\hline 65,058 & $(37,442)$ & 5,060 & $\begin{array}{r}86 \\
718\end{array}$ \\
\hline 24,908 & 8,746 & 228 & 221 \\
\hline 69,772 & $(17,870)$ & 862 & 250 \\
\hline 72,709 & 37,128 & 2,232 & 1,169 \\
\hline 281,631 & 72,011 & 8,336 & 613 \\
\hline 38,213 & 14,242 & - & \\
\hline 9,125 & 2,179 & - & 132 \\
\hline 45,639 & $(7,200)$ & 930 & 206 \\
\hline$(6,355)$ & 3,000 & 1,350 & 37 \\
\hline$(8,000)$ & $(4,441)$ & & (12) \\
\hline 45,606 & $(26,809)$ & - & 85 \\
\hline 1,837 & 1.261 & - & 6 \\
\hline $\begin{array}{c}17,200 \\
5,700 *\end{array}$ & $\begin{array}{l}(9,588) \\
(2,689)\end{array}$ & 200 & 170 \\
\hline 28,642 & $(6,619)$ & 403 & 236 \\
\hline 104,308 & $(96,345)$ & 6,984 & 335 \\
\hline 27,855 & $(11,100)$ & 2,734 & 53 \\
\hline 200,979 & $(47,463)$ & 9,970 & - \\
\hline 45,000 & $(25,000)$ & , & - \\
\hline 2,500 & $(1,426)$ & & \\
\hline 82,300 & $\begin{array}{l}46,104 \\
(6,7\end{array}$ & 1,211 & $\begin{array}{l}399 \\
(200)\end{array}$ \\
\hline $\begin{array}{l}111,790) \\
264,401\end{array}$ & $\begin{array}{l}(46,704) \\
114,963\end{array}$ & 3,798 & 2,070 \\
\hline & & & \\
\hline 702,278 & 627,095 & 164,246 & 32,779 \\
\hline
\end{tabular}

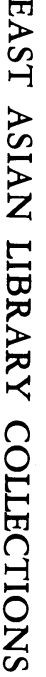

Note: - Zero holding or information not available.

* Figures from previous reports and not up-to-date.

() Figures estimated by reporting library or the investigator.

Western languages.

列

at Asian Art Museum, which was previously known as DeYoung Museum. 
The Chinese collection is represented with holdings over I,, 00 volumes in 86 libraries; Japanese, 76 ; and Korean, 23. The Chinese has a higher ratio of titles versus volumes than the Japanese and Korean. By titles, the total holdings in 93 collections are $54 \%$ in Chinese, $42 \%$ in Japanese, and $3.5 \%$ in Korean; but by volumes, they are $60 \%$ Chinese, $36 \%$ Japanese, $3 \%$ Korean, and I\% other East Asian languages. Of current periodicals, half the titles are in Japanese, $28 \%$ in Chinese, $10 \%$ in Korean, and the rest in Western languages.

The holdings in number of volumes or titles alone sometimes do not reflect the special strength of an individual collection. For this study, information on rarities and specialties reported by thirty-three libraries is also included. The list has briefly identified some thirty rare book collections and over eighty large subject concentrations in individual collections that are not likely to be duplicated elsewhere in American libraries (See Appendix).

The rare book collections located in a dozen or more libraries consist of early and fine printing, old manuscripts, rubbings from bronze and stone inscriptions, and other unusual items. Included are at least 100,000 volumes of $C$ hinese rare books printed in the twelfth to seventeenth centuries, with a few specimens of the eighth and tenth centuries; more than I 3,000 manuscripts and about 4,000 volumes of early and fine printing in Japanese; approximately 10,000 volumes of movable-type printing in Korean; and nearly 5,000 items of rubbings in Chinese and other languages. In addition, xylography and manuscripts in other East Asian languages (e.g., Manchu, Mongol, Moso, and Tibetan) are also well represented.

The large subject collections include almost all kinds of materials in different languages and areas on such broad or specific topics as Confucian classics, Buddhism, biography, genealogy, history and institutions, modern and contemporary affairs, geography, maps, local history and administration, language, literature, drama, novels, individual literary collections, arts, archaeology, science and technology, botany, agriculture, medicine, and military history-as well as such special types of materials as classified encyclopedias, collectanea, archives and documents, posters, handbills, and newspapers. Other special subject collections of significance are believed to exist elsewhere without having been reported by the holding libraries. ${ }^{4}$

The average annual increase during the five-year period I 97 I-75 was 265,000 volumes, a $13 \%$ drop compared with that of 303,000 volumes for the previous period of I 966-70 (Table 2). A downward trend was especially noted in the first half of the period-when rising costs, depreciation of the dollar, and general budget cuts resulted in a $20 \%$ drop in new acquisitions. An upturn was observed during the second half, especially in $1974 / 75$, when three-fourths of the collections acquired more than the average of the previous four years; a total addition of 320,000 volumes was reported. Among all the collections, ten acquired between 10,000 and 30,000 volumes each; others added a few hundred to several thousand volumes during the period. The total addition of $\mathrm{I} .4$ million volumes in $\mathrm{I} 97 \mathrm{I}-75$ produced a $25 \%$ increase in total holdings over that in $1966-70$, in comparison with a $39 \%$ increase for the previous five-year period (Table 2). If the current rate of growth remains around 300,000 volumes a year, as it has since the I960s, the total holdings of East Asian materials should reach or pass the eight million mark by 1980 .

The geographical distribution of the East Asian library resources coincides in

${ }^{4}$ See catalogs and other publications of individual collections in the Library Quarterly, XXIX (1959),

pp. $40-42$; and supplements in the full report, Appendix C, pp. 49-57. 
TABLE 2

GROWTH OF EAST ASIAN COLLECTIONS IN AMERICAN LIBRARIES, 1869-1975 (Unit: 1,000 volumes)

\begin{tabular}{|c|c|c|c|c|c|c|c|c|c|c|c|c|c|}
\hline PERIOD & $\begin{array}{c}\text { NO. OF } \\
\text { COLLECTIONS }\end{array}$ & \multicolumn{5}{|c|}{ NO. OF VOLS. AT END OF PERIOD } & $\begin{array}{c}\text { TOTAL } \\
\text { ADDITIONS } \\
\end{array}$ & $\begin{array}{l}\text { PER CENT } \\
\text { INCREASE }\end{array}$ & \multicolumn{5}{|c|}{ AVERAGE ANNUAL ADDITIONS } \\
\hline $1869-1930$ & 12 & 355 & 32 & - & - & 387 & - & - & - & - & - & - & - \\
\hline $1936-1940$ & 17 & 779 & 90 & - & - & 869 & 309 & 55 & 56 & 6 & - & - & 62 \\
\hline $1941-1945$ & 18 & 938 & 111 & - & - & 1,049 & 180 & 21 & 32 & 4 & - & - & 36 \\
\hline $1951-1955$ & 20 & 1,434 & 742 & - & - & 2,176 & 402 & 23 & 49 & 31 & - & - & 80 \\
\hline $1956-1960$ & 20 & 1,634 & 894 & 23 & 5 & 2,556 & 380 & 17 & 40 & 30 & 5 & 1 & 76 \\
\hline $1961-1965$ & 50 & 2,409 & 1,359 & 75 & 15 & 3,858 & 1,302 & 51 & 155 & 93 & 10 & 2 & 260 \\
\hline $1966-1970$ & 71 & 3,335 & 1,881 & 138 & 22 & 5,376 & 1,518 & 39 & 185 & 104 & 13 & 1 & 303 \\
\hline
\end{tabular}

Note: a Additions include materials mostly in Tibetan acquired through the PL480 program.

Indicates increase/decrease over the previous period.

Source of information: Previous surveys published in the Library Quarterly 29:1 (January 1959), 35:4 (October 1965); CEAL Newsletter 16 (October 1966), 22 (December 1967), 29 (May 1969), and 33 (December 1970); and AAS Newsletter 16:3 (February 1971).

general with that of the membership of the Association for Asian Studies. ${ }^{5}$ Among the 89 collections in the United States, the largest concentration of resources is in the New England-Atlantic Coast area, where 4 I collections (46\%) with 3.5 million volumes $(55 \%)$ and 2,250 members $(48 \%)$ are located. The North Central, or Midwestern area, with I,265 members ( $26 \%$ ), is represented by 23 collections $(26 \%)$ with I. 3 million volumes (20\%); the Pacific area, with 9 I 5 members (I9\%), by 20 collections (23\%) with I.4 million volumes (22\%). The less-represented areas include the Mountain region, with I 66 members (4\%) and four collections (4\%) with a little over I 20,000 volumes ( $2 \%)$; and the South Central, I 62 members ( $3 \%)$ and one collection (I\%) with some 30,000 volumes (i\%). There are also three collections with 300,000 volumes in Canada and two collections of smaller size in Brazil and Mexico $^{6}$ (Table 3).

\section{Acquisitions, Cataloging, and Arrearages}

More volumes were acquired than were cataloged in $1974 / 75$ : during the year, a total of some 320,000 volumes were added but only 280,000 volumes were cataloged, thus making a backlog of I $2 \%$ for new acquisitions and a total of about 250,000 titles in over a half-million volumes uncataloged at the end of the fiscal year. For selection and acquisitions, the average capability rate per person, both professional and clerical, is between $\mathrm{I}, 000$ and 5,000 titles, or an average of 2,000 titles in 3,000 volumes a year. Based on this estimate, one bibliographer and one clerical assistantboth full-time-engaged in selection, searching, ordering, and accessioning, could handle an average of 4,000 titles in 6,000 volumes a year.

The average cataloging rate per person is between 600 and 2,000 titles, or an

\footnotetext{
${ }^{5}$ Based on the membership breakdown in the Asian Studies Professional Review, IV (1974-75), pp. 72-74.
}

${ }^{6}$ The collection at El Colegio de Mexico is includ- ed in the tabulation; that of the Universidade de São Paulo in Brazil, which possessed 1 2,2 10 volumes in Japanese in September 1976 , is not represented. 
TABLE 3

GEOGRAPHICAL DISTRIBUTION OF EAST ASIAN RESOURCES IN AMERICA as of June 30,1975

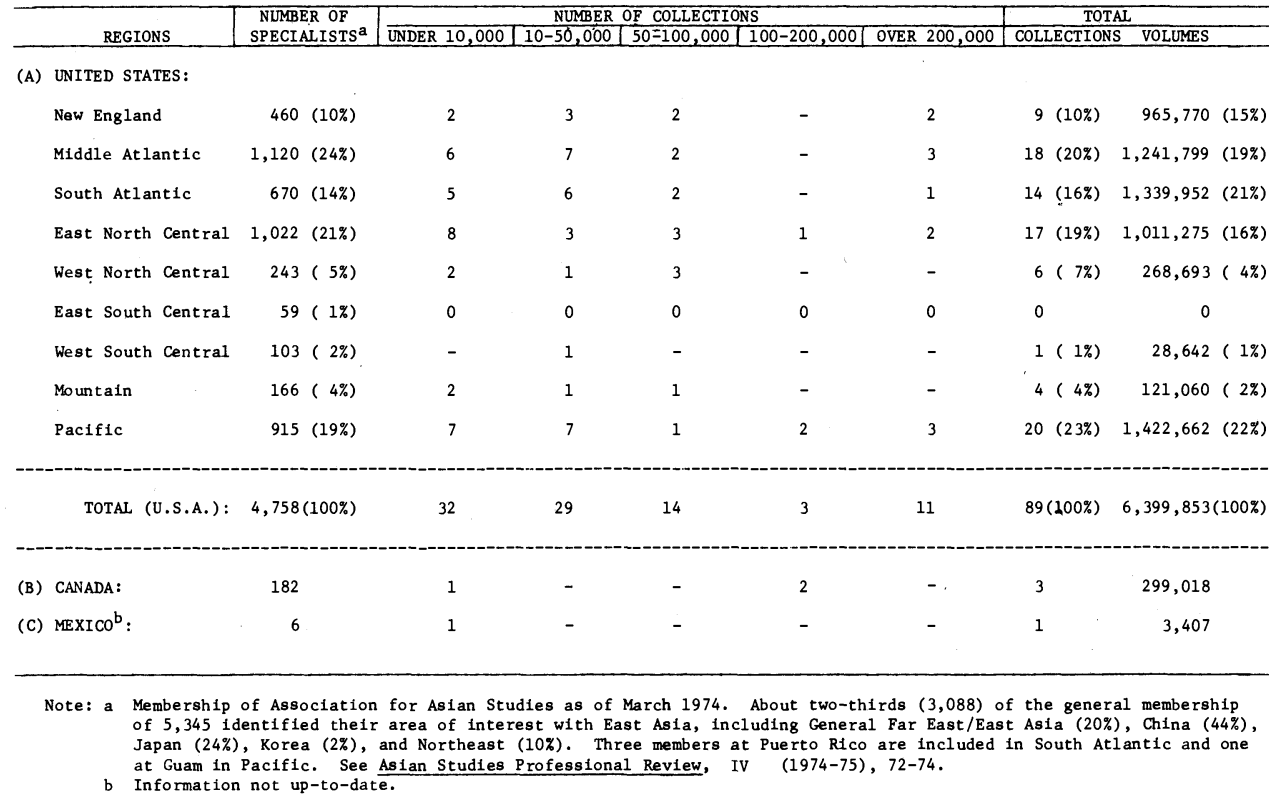

average of $\mathrm{I}, 000$ titles in $\mathrm{I}, 600$ volumes a year. Thus one professional cataloger assisted by one clerical worker in descriptive and subject cataloging, typing, calligraphy, labeling, and filing could process an average of 2,000 titles or 3,200 volumes a year. At that rate, to clear up today's backlog accumulation of 250,000 titles or 500,000 volumes would require the work of at least a dozen professional catalogers plus the same number of clerical assistants for ten years.

The Library of Congress printed cards were adopted by almost all libraries in cataloging. Among a dozen major collections other than the Library of Congress, the percentage of such adoption varied a great deal-from $9 \%$ to $98 \%$ for Chinese, $14 \%$ to $95 \%$ for Japanese, and $8 \%$ to $100 \%$ for Korean. The variation resulted from cataloging more or fewer titles of the pre-1 958 imprints, or from the length of the period set up by different libraries for awaiting the LC cards for adoption. The cataloging of more current imprints and the longer waiting period would permit more use of the LC cards. The average rate of adoption of LC cards was $4 \mathrm{I} \%$ for Chinese, $67 \%$ for Japanese, $39 \%$ for Korean, and $54 \%$ for all languages. According to the reports from different collections, the production rate was not always relevant to the number of LC cards adopted in cataloging. This lack of correlation (coefficient of only -.05) may result from different ways of keeping statistics, or from simple or elaborate cataloging in different libraries. Further study could determine what percentage of efficiency would be achieved if more LC cards were adopted in cataloging.

\section{Personnel, Fiscal Support, and Unit Costs}

A total of 453 librarians, expressed in terms of full-time equivalent (FTE), were employed in $1974 / 75$ to handle East Asian materials in 68 collections. These included 206 FTE persons for Chinese (46\%), I 60 for Japanese (35\%), 29 for Korean (6\%), 
and 58 who deal with all languages, including Western (1 $3 \%$ ). The technical procedures involved I 22 FTE persons (25\%) in acquisitions, including selection, searching, ordering, and accessioning; $205(46 \%)$ in preparations, including cataloging, classification, typing, calligraphy, filing, labeling, and binding; and r $26(29 \%)$ in services, including reference, circulation, maintenance, and administration. Over one-half of the staff (242) were professional librarians, who are normally involved in administration, book selection, cataloging, and reference work; less than one-half (2 I I) were supporting staff members, generally under the supervision of the professional librarians. The size of staffing of individual collections varied in terms of full-time from one or less in smaller collections to as many as 74 at the Library of Congress. The major collections each employed from 10 to 30 (FTE) in acquisitions, cataloging, and services.

There were some 30 vacancies of professional or full-time positions open in 1974-76, including I 2 for curatorships or section heads, 3 for bibliographers or reference librarians, and 15 for catalogers and professional assistants. If openings for this two-year period can be used as a basis for estimate, the annual turnover should be about $5 \%$ of the present professional staff, or an annual need of about ro to 15 professional librarians to fill vacancies as a result of promotions, resignations, or retirement. Although fewer positions are available in recent years than five or ten years ago, when annual opening of some 30 to 75 positions was reported, ${ }^{7}$ the demand for more experienced and highly trained personnel has been persistent.

The cost of operating the East Asian collections went up significantly during the last five years. The total expenditures for $1970-75$ as reported by 78 collections were over 34 million dollars, $66 \%$ higher than those for $1965-70 .{ }^{8}$ The average annual cost of materials was 1.4 million dollars in $1965-70$ and 2 million in $1970-75$, showing a $4 \mathrm{I} \%$ increase. The average annual expenditure for personnel was 2.5 million dollars in $1965-70$ and 4.5 million in $1970-75$, an $82 \%$ increase. The budget for $1975 / 76$, amounting to a total of over 8 million dollars, shows an increase of $5 \%$ for materials, I I $\%$ for personnel, and $16 \%$ for other items-an overall increase of $9 \%$ over the expenditures for $1974 / 75$. Throughout the last decade, almost $90 \%$ of the total revenue for supporting the East Asian collections came from the parent institutions; about $10 \%$ came from outside funding, dropping to $8 \%$ in $1970-75$, but in $1974 / 75$ and $1975 / 76$ back to the same level as in 1965-70 (Table 4).

The unit cost of materials for $1974 / 75$ was $\$ 7.00$ per volume for Chinese, $\$ 8.50$ for Japanese, and $\$ 8.00$ for Korean, with an overall cost of about $\$ 8.00$ per volume. The cost for acquisitions was $\$ 6.00$ per title or $\$ 4.00$ per volume, and for cataloging $\$ 13.00$ per title or $\$ 8.00$ per volume, making the total processing cost $\$$ I 9.00 per title or \$ I 2.00 per volume. Based on these figures, the total cost of the material, acquisition, and cataloging was $\$ 20.00$ per volume. If a library added I, 000 volumes in $1974 /$ 75 , the cost was a total of $\$ 8,000$ for materials and $\$ 12,000$ for acquisitions and cataloging. Thus, for every dollar spent on materials, \$1.50 was spent for processing. If service cost is added, the total would be $\$ \mathrm{I} .00$ for materials and operating expenses, and $\$ 2.00$ for salaries.

\footnotetext{
${ }^{7}$ See my Present Status and Personnel Needs of Far Eastern Collections in America: A Report for the Committee on American Library Resources on the Far East of the Association for Asian Studies (Washington, D.C., I 964); see also T. H. Tsien and Howard W. Winger (eds.), Area Studies and the Library (Chicago: Univ.
}

of Chicago Press, 1966), pp. 68-7 I.

${ }^{8}$ The total expenditure for the 22 collections not included in the previous surveys were $\$ 1,983,103$, or $5 \%$ of the total; thus the true total of increase was 6 I\%. 
TABLE 4

FISCAL SUPPORT OF EAST ASIAN COLLECTIONS IN AMERICAN LIBRARIES 1965-1976

\begin{tabular}{|c|c|c|c|c|c|c|c|c|}
\hline \multirow{2}{*}{$\begin{array}{l}\text { FISCAL } \\
\text { YEAR }\end{array}$} & \multicolumn{3}{|c|}{ TYPES OF EXPENDITURES } & \multicolumn{4}{|c|}{ SOURCES OF REVENUE } & \multirow[b]{2}{*}{ TOTAL } \\
\hline & MATERIALS & \begin{tabular}{|l|} 
SALARIES \\
\end{tabular} & OTHER ${ }^{\mathrm{a}}$ & OWN INST. & $\mathrm{HEW} / \mathrm{NEH}$ & FOUNDATION & OTHER ${ }^{\mathrm{D}}$ & \\
\hline \multicolumn{9}{|l|}{$1965 / 1970$} \\
\hline TOTAL & $\$ 7,002,515$ & $\$ 12,449,825$ & $\$ 1,154,826$ & $\$ 18,195,929$ & $\$ 806,068$ & $\$ 1,378,165$ & $\$ 227,004$ & $\$ 20,607,166$ \\
\hline AVERAGE & $1,400,503$ & $2,489,965$ & 230,965 & $3,639,186$ & 161,213 & 275,633 & 45,401 & $4,121,433$ \\
\hline PER CENT & $34 \%$ & $60 \%$ & $6 \%$ & $88 \%$ & $4 \%$ & $7 \%$ & $1 \%$ & $100 \%$ \\
\hline \multicolumn{9}{|l|}{$1970 / 1975$} \\
\hline TOTAL & $9,860,196$ & $22,711,271$ & $1,666,548$ & $31,421,986$ & $1,092,988$ & $1,554,796$ & 168,245 & $34,238,015$ \\
\hline AVERAGE & $1,972,039$ & $4,542,254$ & 333,310 & $6,284,397$ & 218,598 & 310,959 & 33,649 & $6,847,603$ \\
\hline PER CENT & $29 \%$ & $66 \%$ & $5 \%$ & $92 \%$ & $3 \%$ & $4.5 \%$ & $0.5 \%$ & $100 \%$ \\
\hline $\begin{array}{l}\text { CHANGE } \\
\text { OVER } 65 / 70\end{array}$ & $+41 \%$ & $+82 \%$ & $+44 \%$ & $+73 \%$ & $+36 \%$ & $+13 \%$ & $-26 \%$ & $+66 \%$ \\
\hline \multicolumn{9}{|l|}{$1974 / 1975$} \\
\hline TOTAL & $2,165,985$ & $4,898,203$ & 332,227 & $6,555,618$ & 237,043 & 518,466 & 85,288 & $7,396,415$ \\
\hline PER CENT & $29 \%$ & $66 \%$ & $5 \%$ & $89 \%$ & $3 \%$ & $7 \%$ & $1 \%$ & $100 \%$ \\
\hline \multicolumn{9}{|l|}{$1975 / 1976$} \\
\hline BUDGET & $2,269,358$ & $5,419,341$ & 383,849 & $7,148,843$ & 320,422 & 539,149 & 64,134 & $8,072,548$ \\
\hline PER CENT & $28 \%$ & $67 \%$ & $5 \%$ & $88 \%$ & $4 \%$ & $7 \%$ & $1 \%$ & $100 \%$ \\
\hline $\begin{array}{l}\text { CHANGE } \\
\text { OVER } 74 / 75\end{array}$ & $+5 \%$ & $+11 \%$ & $+16 \%$ & $+9 \%$ & $+35 \%$ & $+4 \%$ & $-25 \%$ & $+9 \%$ \\
\hline
\end{tabular}

Note: a Includes expenses for equipment and supplies, postage and telephone, travel and other items. An estimate of $5 \%$ of the total expenses for materials and personnel is added for those not reporting the figures under this item.

Includes endowment, gifts, and miscellaneous income. 


\section{Access, Patrons, and Services}

Information concerning use and services is incomplete; many collections did not keep such records as were requested, or their services were managed by their parent library. From the figures reported, however, some general patterns of use may be noted. In all university and college libraries, the collections were used not only by their own faculty members and students but also by a variety of visitors, who constituted from one-third to one-half of the total clientele. Most visitors came from one hundred miles or more away; most, including those from foreign countries, came for reference or research purposes. Most of the collections were established to support graduate studies; with a few exceptions, they did serve more graduate than undergraduate students. Most of the visitors were faculty members or students from other academic institutions; but business, industry, and government employees were also among the patrons. For public and federal libraries, all patrons were reported as visitors.

In general, circulation figures are relevant to the size of individual collections and size of faculty and student enrollment. Eleven collections circulated 10,000 to 20,000 volumes and six circulated 30,000 to 60,000 volumes, representing about 6-1 5\% (an average of $8 \%$ ) of their individual total holdings. More Chinese than Japanese materials were circulated; the figures were generally compatible with the ratio of their total holdings in Chinese (60\%) and Japanese (36\%). In inter-library loans, most of the major collections lent out more books than they borrowed from other libraries. The figures show that from less than $1 \%$ to as much as $10 \%$ of the total circulation, including photoduplication requests, was lent by one library to others.

All the university and college libraries were open from 40 to over 100 , with a majority between 50 and 70 , hours per week; other libraries were open around 40 to 50 hours a week. They are all accessible to visitors for reference use, but some of the private institutions charged a fee as high as $\$ 400$ or $\$ 500$ for borrowing privileges, to compensate for the cost of handling and servicing.

\section{Summary, Problems, and Recommendations}

Compared with that of the previous decade, ${ }^{9}$ the development of East Asian collections in American libraries during the period $197 \mathrm{I}-75$ was in a general state of stagnation and retrenchment. During this recent five-year period, only a few major collections showed a moderate gain in acquisitions; most of the other collections suffered a loss from the growth they had achieved in the r 960 s. A few of them have become inactive, or their programs have been indefinitely suspended. Inflation and budgetary cuts certainly were major reasons for the difficulties, but other factors also contributed to the complexity of the problems. Greater dependence on original and manual work in technical operations, fewer useful reference tools, higher unit costs, and less coordination and cooperation among the collections (in comparison with their Western-language counterparts) are some of the problems involving economy and efficiency. More recently, attention has been called to rationalization of acquisitions, improvement of accessibility, sharing of resources, and upgrading of personnel-all of which need overall and careful planning.

The rapid growth of the field during the 1960 s was primarily through the massive support of the language-area studies provided by the federal government and private

\footnotetext{
${ }^{9}$ See my "East Asian Library Resources in Ameri- $\quad$ pp. I-I I. ca: A New Survey," AAS Newsletter, XVI, 3 (I 97 I),
} 
foundations. Although the outside funding in support of the libraries has been around only 10\% of the total investment, encouragement in the form of matching or development funds stimulated the institutional initiative. The retrenchment during the early I 970 s resulted primarily from the reorientation of federal aid and the termination of foundation grants, in addition to the shift of priorities in certain institutional programs. The recent infusion of money to the field from several granting agencies (especially the Japanese sources and the Andrew W. Mellon Foundation) has revitalized the activities in some of the collections, but the temporary nature of these grants provides no guarantee for future development. For long-range planning, a review of funding potentials is a necessity. ${ }^{10}$

For future resource development and accessibility, there is a need to define the goals and policies of both individual collections and the field as a whole. What level of a collection should be developed to meet the local needs? What kind of cooperation is possible in acquisitions and resource-sharing on the regional, national, or international level? For guiding individual collections to maintain standards on different levels, checklists of basic and reference collections should be compiled. To provide necessary information to the users, union lists of special subject fields or types of materials should be published. A handbook describing essential resources, facilities, and services available in various collections would be a most desirable basic research tool for scholars, students, and librarians. The brief identification of rarities and specialties (See Appendix) and of publications by and about individual collections (See full report) in this study would serve as the first step toward attaining some of these goals.

For improvement of technical operations, still more effort should be made toward achieving efficiency and economy in unit capabilities and costs through cooperative acquisitions and cataloging. The possible introduction of the NPAC program to cover China and Korea would solve part of these problems. Special attention should then be given to the coordinate use of the Harvard-Yenching classification scheme; adopted by seven of a dozen major collections, it now controls more than $60 \%$ of the total resources and two-thirds of new acquisitions. Until cooperation among its users to eliminate duplicate efforts in this area is realized, other efforts solve only part of the cataloging problems of the field.

Another problem is that of preservation and conservation of East Asian materials. Not only do hundreds of thousands of rare documents and old printed editions need special care or restoration (which needs highly specialized techniques in which no expert is available in this country), but new materials also will soon deteriorate. Almost all the Chinese materials published in this century are on newsprint or acid paper, which cannot last more than fifteen to twenty years under normal conditions. Is it worthwhile to acquire such materials, with elaborate rebinding and processing, only to abandon them after a short period? Most users do not like microforms; yet, what other alternatives are there?

In solving some of these technical and academic problems, there is a greater need today than ever before for research in East Asian librarianship. How can modern library techniques be applied to the East Asian library field to achieve efficiency and economy? Can we preserve and perpetuate the traditional scholarship of historical bibliography, or bibliology for handling rare and old materials in the East Asian

\footnotetext{
${ }^{10}$ American Council on Education, Library Services in Support of International Education (Washing-
} 
collections? Serious research is needed in such problems as replacing manual work with more efficient devices, automation of technical and service procedures, methods of conservation and preservation, photoduplication and micro-publishing, critical review of adequacy of both the LC and Harvard-Yenching classification systems, and application of certain management skills for improvement of organization and administration. Historical bibliography-including study of the format, materials, and methods of bookmaking; distribution; and collecting-is a major discipline in Oriental and European scholarship. Concern has been expressed that, if it is not properly preserved and transmitted to the younger generation, it may/possibly disappear from American scholarship. ${ }^{11}$ Methods of teaching and research in this field constitute another major problem in East Asian librarianship.

Finally, an adequate program is needed for training better-qualified personnel to serve in the East Asian field in American libraries. ${ }^{12}$ The problems involve attracting the best-qualified students to the field, strengthening teaching staff and curriculum, preparing needed teaching and reference materials, and placing the qualified candidates in appropriate positions. All these need careful planning and substantial funding to improve both the quality and the quantity of the present program in order to adequately meet the demand for qualified library personnel for administrative, technical, teaching, and research positions in East Asian studies.

\section{APPENDIX \\ Rarities and Specialties of East Asian Materials in American Libraries}

\section{University of British Columbia Library. Asian Studies Division}

P'u-pan Collection: 3,226 titles in 43,320 volumes. Includes $86 \mathrm{Kwangtung}$ gazetteers and 300 rare items of Sung, Yüan, Ming printing and mss. (See Wang Yi-t'ung, A Descriptive Catalogue of Valuable Manuscripts and Rare Books from China Issued during the Sung, Yüan and Ming Dynasties, 960-1644, I959; also "The P'u-pan Chinese Library at the University of British Columbia," Pacific Affairs, XXXIV [ I 96 I ], pp. IOI-II).

\section{University of California, Berkeley. East Asiatic Library}

Rare book collection: 335 titles in 2,80 I volumes. Primarily Chinese imprints before I 644 and Japanese imprints before 1600 .

Chinese rubbings: $2, \mathrm{IO}_{4}$ items. Rubbings from steles, monuments, statues, bronzes, tiles, etc.

Ho-Chiang Collection of Buddhist literature: I I 0 titles in I 46 volumes. Includes early Chinese, Japanese, and Korean woodblock editions; and mss. written in gold or silver.

John Fryer Collection of Chinese translations of Western scientific and technical works by the Kiangnan Arsenal in I 867-1902: over 100 titles in ca. I,500 volumes.

Japanese manuscripts: ca. 7,000 pieces, only a few of which have been published.

Japanese woodblock printed maps: 1,963 titles in 2,049 items. I 7 th-1 9 th century woodblock printed maps, with some in color.

Murakami Library of Meiji literature: ca. 8,000 titles in 8,850 volumes. Japanese belles lettres and works on philosophy, society, and politics of Meiji period, mostly first editions.

Asami Library of Korean literature: ca. I,000 titles in 4,000 volumes. Classical Korean imprints and mss. I 6th-I 9 th centuries (See Fang Chaoying, The Asami Library: A Descriptive Catalogue, Berkeley: University of California Press, I969).

Tibetan Xylographs: I,406 fascicles. Includes Tantric texts of Nying-ma-pa Sect and Narthang editions of Kanjur.

\section{University of California, Los Angeles. Oriental Library}

Chinese archaeology: ca. I,000 titles in 3,000 volumes. Includes reproductions, reports, and studies of various fields of Chinese archaeology.

\footnotetext{
${ }^{11}$ Frederick W. Mote, "Library Skills in the Chinese Field," CEAL Newsletter, No. 47 (I975), pp. $75-76$.

${ }^{12}$ For qualifications and problems, see my "Edu-
}

cation for East Asian Librarianship," in Enid Bishop and Jean M. Waller (eds.), Intellectual Cooperation in Oriental Librarianship (Canberra: National Library of Australia, I972), pp. I08-1 5 . 
Ch'en's Collection on Chinese literature and poetry of the Ch'ing dynasty: 240 titles in I,26I volumes.

Toganoo Collection on Buddhism: 342 titles in 968 volumes.

\section{Center for Research Libraries (Chicago)}

Edward Hunter Collection: seven shelves of uncataloged Chinese Communist publications. Includes news releases pertaining to "confessions" by Americans, newspaper clippings on alleged American germ warfare, textbooks, propaganda periodicals, and picture books. Most of the materials are in Chinese; some are accompanied with manuscript translations in English.

Union Research Institute files: ca. 2,000 reels of microfilm. Of newspapers, periodicals, and classified files published in the People's Republic of China r949-1966.

\section{University of Chicago. Far Eastern Library}

Chinese rare book collection: 394 titles in I 4,059 volumes. Includes 3 chuan of Tun-huang mss., one Dharani printed in 975 , one complete set of the northern edition of Ming Tripitaka (multi-color) and other pre-I 644 printing (Fine and early $\mathrm{Ch}^{\prime}$ ing editions are not included).

Li Tsung-t ung Collection of Ming printing and mss: 33 I titles in 2,23 I volumes. Chinese rare books and mss., mostly copied or printed during the Ming dynasty, including a I $523 \mathrm{~ms}$. of Tao ching with color frontispiece, 528 sheets of letters on ornamental stationery by P'an Tsu-yin (i 830-90).

Sealing clay inscriptions: I i impressions on Io pieces, representing official titles of central and local administrations of the Han dynasty ca. the beginning of the Christian era (See Far East: An Exbibition of Resources in the University of Chicago Library, I973).

Berthold Laufer Collection: 2 I,403 volumes. In Chinese, Japanese, Manchu, Mongol, and Tibetanacquired during Dr. Laufer's expedition to the Far East I 907-19 I 0 (See Berthold Laufer, Descriptive Account of the Collection of Chinese, Tibetan, Mongol, and Japanese Books in the Newberry Library, Chicago, I 9 I 3; also John R. Krueger, "Catalogue of the Laufer Mongolian Collection in Chicago," Journal of the American Oriental Society, LXXXVI [1966], pp. I 56-83).

Confucian classics: ca. 4,000 titles. Includes I, 560 separate works in 16,000 volumes, of which 66 titles in 720 volumes are rare editions printed I 5 th- I 7 th centuries, or formerly in the collection of T'ien I Ko and Hsü Nai-ch'ang, or with critical notes by eminent scholars.

Chinese local histories: over 2,700 titles in I 7,000 volumes. Mostly in original editions; a few photoreproduced copies of rare editions from Chinese and Japanese libraries. Especially strong on Kiangsu, Chekiang, Honan, Hopei, Shantung, and Shensi (See Reference List, No. I, Chinese Local Histories, Chicago, 1969).

Chinese local administration: 2, I 85 titles in 3,240 volumes. Includes reports and gazettes of local governments; statistics; and descriptions of local conditions on provincial, municipal and county levels (Not included in the collection on local histories.)

Documents from wartime Shanghai, I 94I-I 945: 296 items. Leaflets, posters, photographs, maps, ID cards, ration coupons, flags, postage and tax stamps, paper currencies, and underground newspapers issued under Japanese occupation; and first editions and extras of papers published on VJ day (collected by T. H. Tsien).

Chinese student demonstration handbills: 72 original handbills issued by student groups in Peking and Tientsin during mass demonstrations in 1947 and 1948 .

Rare Japanese materials: 52 titles in I 50 volumes published during the Tokugawa period on Japanese arts; and 23 titles in $7 \mathrm{I}$ volumes on Japanese calligraphy and paintings.

Claremont Colleges. The Honnold Library. Asian Studies Collection

Frederick McCormick Collection: I I 8 titles in 773 volumes. Movable-type editions of Korean printed books I 5 th-igth centuries.

\section{Cleveland Museum of Art. Library}

Oriental fine arts: 3,560 titles in 7,172 volumes. In Oriental and Western languages.

\section{Columbia University. East Asian Library}

Chinese genealogy: 994 titles in 10,507 volumes. Cbia-p' $u$; the largest collection of these materials in the Western world (See Akigorō Taga, Söfu no Kenkyū shiryō hen [Tokyo, i 966], pp. 370-450).

Chinese local histories: I,622 titles in 16,794 volumes (See Chu Shih-chia, "Chinese Local Histories at Columbia University," Harvard Journal of Asiatic Studies, VIII [1944-45], pp. I 87-95).

A complete set of the original edition of Kuchin t'u shu chich'eng in 5,000 volumes, donated to Columbia by the Manchu court.

A collection of 30 scrolls of the scenery along the Yangtze, collected by Fukuda Disen.

A collection of 236 facsimile scrolls of ancient Japanese records.

A collection of Manchu, Mongol, and Tibetan materials. Includes a Narthang edition of the Tibetan Tripitaka printed I $730-1732$.

Yi Sŏng-ŭi Collection of Korean movable-type editions: 586 titles in 2,04 I volumes. 


\section{Cornell University. Wason Collection}

Early Western-language works on East Asia: largest group of such works on China published I 5th-i 8th centuries. Consists of correspondence and private documents relating to Lord Macartney's embassy to China.

Field Museum of Natural History (Chicago)

Chinese rubbings: ca. 2, O I 3 titles of Chinese rubbings and albums, including groups of individual rubbings for one title. Also includes a complete collection of Jesuit tomb inscriptions (A descriptive catalog is under preparation).

\section{Freer Gallery of Art. Smithsonian Institution}

Far Eastern art collection: works on Far Eastern art, with a number of rare items in Chinese and Japanese.

Genealogical Society Library (Salt Lake City, Utah)

Chinese clan genealogies: 1,200 titles in 900 reels of microfilm. Reproduced from collections in the U.S., Japan, Hong Kong, and Taiwan, including over 400 titles of local Taiwan genealogy.

Japanese clan genealogies: 800 reels of microfilm. Reproduced from the Miyogi and Yamaguchi prefectural archives.

Korean clan genealogies: 2,000 titles in I,500 reels of microfilm. Reproduced from Korean and U.S. collections.

Korean local histories: roo reels of microfilm. Reproduced from collections in Korea.

\section{Harvard University. Harvard-Yenching Library}

Chinese rare book collection: includes I 4 titles in 66 volumes and I 3 folders of Sung editions; 36 titles in 653 volumes, I roll, 3 folders and I leaf of Yüan editions; I, 2 I 9 titles in I8,0 I 3 volumes of Ming editions; I, 065 titles in I I,739 volumes published in early Ch ing; I, I 28 titles in 4,074 mss. written I 4 th- I 9 th centuries, of which I, I 03 volumes are original mss. of local government and music books.

Ming multi-color printed books: 72 titles in ca. 220 volumes. Issued by the Min and Ling families I 580I 644, when a total of I 44 titles are known to have been printed.

Chinese rubbings: 300 titles in 400 folded volumes and sheets.

Chinese local histories: 3,525 titles in ca. 35,000 volumes. Especially strong in those printed in K'ang-hsi, Yung-cheng, and $\mathrm{Ch}$ 'ien-lung periods of early $\mathrm{Ch}$ 'ing.

Ch'i Ju-shan Collection of Chinese drama and novels: 72 titles in 328 volumes. Forms one of the three noted collections, which include a few rare items of erotic nature that were proscribed.

Chinese classified encyclopedias: 1,300 works in ca. 26,000 volumes. Includes the movable copper-type edition of the T'ushu chich'eng printed in 1726 (See Ch'iu K'ai-ming, "An Annotated Catalogue of Ming Encyclopedias, and Reference Works in the Chinese-Japanese Library of the Harvard-Yenching Institute at Harvard University, I," Tsing Hua bs ̈̈̈b pao, II [1961], pp. 93-I I 5).

Chinese collectanea: 1,400 works in 60,000 individual titles. Includes 98 original editions of the $100 T s^{\prime} u n g$ shu chi ch'eng.

Bruno Petzold Collection of Japanese Buddhist materials: I,209 titles in 4,385 volumes. Includes ca. 200 mss. dating I 3 th or I 4 th century.

Korean rare book collection: includes I 90 titles in 635 volumes.

Korean genealogy: 523 titles in 2,064 volumes.

Korean biography: $4 \mathrm{I} 6$ titles in 540 volumes. On persons deceased before I 9 I 0.

Korean geography: I 45 titles in 278 volumes. Mostly local gazetteers.

Korean government examination rosters: 233 titles in 269 volumes. Covers the Yi Dynasty I $392-1894$.

\section{University of Hawaii. Asia Collection}

Collection on Hokkaido, Sakhalin and the Kurile Islands: I,978 titles of source materials.

Collection on Ryukyu and Satsuma: ca. 5,000 titles of source materials at the Ryukyuan Center.

Korean local histories: 176 titles in 475 volumes. Published I 850-I900; in Xerox and microfilm.

Korean civil service examination materials of the Yi Dynasty: 30 reels of microfilm.

Hinomoto Library (Los Angeles)

Collection of original ukiyoe: 200 items of color prints.

\section{Hoover Institution. East Asian Collection}

Materials on Chinese economy: 800 titles in I, 400 volumes. On agriculture, banking, and industry in China I 920 s-I 949.

Left-wing publications: 1,200 titles in I,800 volumes. Includes pamphlets, serials, and monographs published I920s-1949.

Chinese student movement collection: 90 titles in 150 volumes. Includes pamphlets, serials, and monographs published 1920-1949 (See Hellen Snow, Notes on the Chinese Student Movement, 1935-1936: 
Guidance Notes Prepared for the Nym Wales Collection on the Far East in the Hoover Institution on War, Revolution and Peace at Stanford University, I 959).

Japanese colonial surveys: 800 titles in I ,600 volumes. Administrative surveys; reports; periodicals; special population studies on Taiwan, Manchuria, Korea, and North China during Japanese occupation I 895I945.

Japanese materials on Chinese Communism: includes 40 titles in 60 volumes produced in China on special military and Shin-min-kai studies.

Japanese left-wing materials: 600 titles in I,200 volumes. Includes pamphlets, serials, and monographs published during the I920s and I930s.

Japanese student movement materials: includes 300 titles in ca. 400 volumes. On Japanese university student movement i 968-70.

University of Illinois. Far Eastern Library

Early and fine Japanese printing: i 25 titles in 486 volumes.

\section{Library of Congress}

Chinese rare book collection: ca. 2,000 titles. Includes I I of Sung imprint; I of Chin; I 4 of Yüan; I,5 I 8 of Ming; 70 of early Ch'ing; 140 in mss.; and 93 others (See A Descriptive Catalog of Rare Cbinese Books in the Library of Congress, Washington, D.C., I 957,2 v.).

Rare works on Chinese medicine: 303 reels of microfilm. Rare medical writings in the former Peking Union Medical College Library.

Chinese local histories: 3,750 titles in ca. 60,000 volumes. Especially strong on such provinces as Hopei, Shantung, Kiangsu, Szechuan, and Shensi (See A Catalog of Chinese Local Histories in the Library of Congress, 1942).

Old Chinese maps in mss.: 80 items. Includes an atlas prepared in the Ming dynasty; mostly collected by Warner and Hummel i 929-30.

Pre-Republican Chinese legal materials: 295 titles in 5,240 volumes. Covers all dynastic periods of Chinese history. (Housed in the Far Eastern Law Division.)

Chinese individual literary collections: 4,700 titles. Wen-chi or pieb-chi, especially strong of the Ch'ing period.

Chinese collectanea: 3,000 titles. Ts'ung-sbu.

Local Chinese newspapers from the People's Republic of China: ca. I,200 titles published in the I950s and I 960 s, of which 80 titles have been microfilmed.

Japanese rare book collection: includes ca. 2,000 titles in 5,000 volumes of mss. and 30 titles in I50 volumes of fine printing.

Special collections of Japanese materials: includes the Crosby Stuart Noyes Collection of Japanese art, acquired I 906; the Kanichi Asakawa Collection with strong emphasis on Buddhism, acquired I 907 ; the Shio Sakanishi Collection with many pre-Meiji works and popular illustrated books of the late Tokugawa period, acquired I930-I 942.

Tokugawa legal documents: I, 000 volumes. Mostly in mss.

Naimushō thought control materials: includes 5,000 items.

South Manchurian Railway Publications: ca. 3,000 volumes (See John Young, The Research Activities of the South Manchurian Railway Company, 1907-1945: A History and Bibliography, New York: East Asian Institute, Columbia University, I966).

Japanese mathematical books: I,০০০ volumes. Mostly published during the late Tokugawa period.

Korean individual literary collections: 40 titles in 200 volumes. Munjip in mss.

Moso manuscript collection: 3,038 volumes. Written in Moso (Nahsi) script.

University of Maryland. East Asian Library

Prange Collection of Japanese publications under U.S. occupation: ca. I 3,000 periodical titles; I I,000 newspaper titles; and 50,000 monographs published in Japan 1945-49 and submitted to the Civil Censorship Detachment Headquarters for pre- or post-publication censorship.

\section{University of Michigan. Asia Library}

I Ching Collection: 32 I titles. Includes commentaries, expositions, and special studies of the Book of Changes.

Chinese local histories: 2,29 I titles. In book form, plus microtext and other photoreproductions from major collections (See A Checklist of Chinese Local Gazetteers in Asia Library, i 968).

Crump Collection of rare Chinese novels: includes 67 rare editions of Chinese popular novels microfilmed from Japanese collections.

British Public Record Office file on China: 3, O 4 reels of microfilm. Includes General correspondence (I 8I 5-I 9I 2), Embassy and consular archives (I 759-I95I), and Confidential print (I 848-I 957).

Union Research Institute files: 2,045 reels of microfilm. Includes I, 395 reels of classified files, 716 periodical titles, and 400 newspaper titles published in the People's Republic of China 1949-1966. 
Classified files on the Cultural Revolution: 2 I 8 classified files. Prepared by the Contemporary China Research Institute of Hong Kong.

Harley Harris Bartlett Collection of Japanese botany during the period of woodblock printing: I 57 titles in 576 volumes.

Selected documents from the archives of the Ikeda family of the Okayama domain: 355 volumes of photostats.

Collection of scripts of Japanese drama: 8,242 scripts presented in 1946-1949.

Pacific War and Occupation Collection: includes 180 volumes in the SCAP Combat Monograph Series, 76 reels of English translations of the SCAP Series, 200 volumes on International Military Tribunal records, and I0,000 sheets relating to Colonel Hussey's papers on drafting the new Constitution.

Military Academy (West Point). Library

Military history of China from the late Ch'ing to I 950: about 200 volumes in Chinese, some of which are rare.

Missouri Botanical Garden (St. Louis)

Chinese and Japanese botanical works: includes ca. I oo titles on Japanese and Chinese gardens and flower arrangements, 300 titles on botanical explorations in East Asia, and 200 titles on studies of East Asian florals.

National Agricultural Library (Beltsville, Maryland)

Collection consists of works on agricultural science, biological science, agricultural economics, and rural economy of China, Japan, and Korea.

National Library of Medicine (Bethesda, Maryland)

Works on the history of Chinese and Japanese medicine.

Nelson Gallery of Art (Kansas City, Missouri)

East Asian art: 2,348 items of cataloged books and 599 bound periodical volumes in the Oriental Library and about 2,000 extra volumes from the Sickman and Wilson Collections, mostly on Chinese painting, ceramics, sculpture, and furniture; Japanese painting, ceramics, and prints; and Tibetan painting and sculpture.

New York Public Library. Reference Dept. Oriental Collection

Publications from the Taiping Kingdom: 24 titles printed by the Taiping Kingdom I 852-6I.

Rare Japanese illustrated materials: includes $300 \mathrm{mss}$. and I,200 books 8th-1 2 th centuries, mostly preMeiji, in the Spencer Collection of illustrated books.

Korean mss. at the Horace Allen Collection.

University of Pittsburgh. East Asian Library

Collection on Taiwan: I,250 titles in 2,654 volumes. On the historical development of Taiwan since Koxinga, I 624-I 662.

\section{Princeton University. Gest Oriental Library}

Rare book collection: includes 3 titles in 778 volumes of Sung editions; 4 titles in 2,086 volumes of Yüan editions of Buddhist sutras; I,084 titles in 24,024 volumes of Ming editions (See Ch'ü Wan-li, $A$ Catalogue of the Chinese Rare Books in the Gest Collection of the Princeton University Library, Taipei: Yee Wen, I974).

Collection on Chinese medicine: I, I 60 titles in I, 620 volumes. Forms the strongest collection of these materials in the Western world.

Japanese Go Collection: 229 titles in 514 volumes. In Japanese from American Go Association.

San Diego State University Library. Asian Collection

Japanese military history of World War II: 200 titles in 250 volumes. Biographies, war records, etc.

Seton Hall University. McLaughlin Library. Asian Collection

Chinese bilingual education: 500 titles in 700 volumes. Strong in bilingual materials.

University of Toronto. East Asian Library

Rare book collection: 3,862 volumes of mss. and printed editions. From Sung to early Ching.

University of Washington. Far Eastern Library

Joseph Rock Collection on Southwest China: ca. 2,000 volumes.

Collection of modern Chinese poetry, I 9 I 9 to date: ca. 700 titles.

Collection of ca. I,, 00 pieces of folk literature $m u-y \ddot{u}-s b u$. 
A file of ca. 400 items of periodicals and pamphlets on the Tiao-yu-t'ai movement in the U.S.

Robert Paine Collection on Japanese painting: 4,097 volumes.

Collection of ca. I,, 00 titles of old and new Korean poetry.

Yale University. East Asian Collection

Jen Yu-wen Collection on Taiping Kingdom: over 320 titles in 640 volumes. Books, periodical issues, mss., rubbings, maps, coins, seals, and clippings related to the Taiping revolutionary movement (See A. Suddard, "Jen Yu-wen Collection on the Taiping Revolutionary Movement," Yale University Library Gazette, No. 49 [1975], pp. 293-96).

Yale Association of Japan Collection on Japanese culture: 680 items. Books, mss., paintings, calligraphy, and objects to illustrate the evolution of Japanese culture 8 th-i 9 th centuries. 